\title{
PENGARUH PEMBERIAN YOGHURT KEDELAI HITAM (BLACK SOYGHURT) TERHADAP KADAR KOLESTEROL LDL DAN KADAR KOLESTEROL HDL PADA PENDERITA DISLIPIDEMIA
}

\author{
Ardisya Rucita, Hesti Murwani $\mathbf{R}^{*}$ \\ Program Studi Ilmu Gizi Fakultas Kedokteran Universitas Diponegoro \\ Jl.Dr.Sutomo No.14, Semarang, Telp (024) 8453708, Email : gizifk@ undip.ac.id
}

\begin{abstract}
Background : Dyslipidemia is one of the risk factors of cardiovascular disease. Soybean is alternative and effective food to decrease level of blood cholesterol. Black Soyghurt contains anthosianin and isoflavon which can decrease LDL levels and elevate HDL levels.

Method : This research used true experimental design with control group pre-test-post-test. Subjects were dyslipidemia men with LDL levels more than 100mg/dL and HDL levels less than 40mg/dL. They were divided in 3 groups, i.e control group, first treatment group (115mL of Black Soyghurt per day), and second treatment group (225mL of Black Soyghurt per day) for 21 days. Subjects had fasting for \pm lOhours before their blood were taken. Blood cholesterol levels were measured by Phosphotungistic Precipilation method. LDL levels were counted with Friedewald formula. Consuming food of subjects was controlled with recommendation and counselling. Normality test used Shapiro-Wilk. Statistic analysis used paired t-test and Kruskal-Wallis. Wilcoxon test was used to abnormal data. Correlation test used Pearson for normal data, whereas Spearman was used to abnormal data.

Result : $115 \mathrm{~mL}$ and $225 \mathrm{~mL}$ of black soyghurt can prove decreasing LDL levels to $2.73 \%$ and $0.099 \%$, respectively. However, both did not have meaning statistically. $225 \mathrm{~mL}$ of black soyghurt elevated HDL levels (10.26\%). Black soyghurt with $115 \mathrm{~mL}$ dose decreased HDL levels $(2.71 \%)$.

Conclusion : 115mL and 225mL of black soyghurt can decrease LDL levels to $2.73 \%$ and $0.099 \%$, respectively during 21 days. Those can also elevate HDL (10.26\%). Black soyghurt decreases HDL (2.71\%).
\end{abstract}

Keywords : black soyghurt; HDL levels; LDL levels; dyslipidemia

\begin{abstract}
ABSTRAK
Latar Belakang: Dislipidemia merupakan salah satu factor risiko penyakit kardiovaskuler. Kedelai hitam merupakan bahan makanan alternatif yang efektif menurunkan kadar kolesterol darah. Yoghurt kedelai hitam mengandung anthosianin dan isoflavon yang diduga mampu menurunkan kadar kolesterol LDL dan meningkatkan kadar kolesterol HDL.

Metode : Jenis penelitian adalah true experimental dengan rancangan control group pre-test-post-test. Subyek adalah pria dislipidemia, kadar kolesterol LDL>100mg/dL, kadar kolesterol HDL<40mg/dL, dibagi menjadi 3 kelompok, kontrol, dan perlakuan I (115 ml yoghurt kedelai hitam/hari), dan perlakuan II (225 ml yoghurt kedelai hitam/hari), diberikan selama 21 hari. Sebelum pengambilan darah, Subjek dipuasakan selama $\pm 10 j a m$, kadar kolesterol darah dihitung dengan metode Phosphotungistic precipilation. Kadar kolesterol LDL dihitung dengan rumus Friedewald. Asupan makan sehari-hari ketiga kelompok dikontrol sesuai dengan anjuran dan konseling yang telah diberikan. Uji normalitas menggunakan Shapiro-Wilk. Analisis statistik menggunakan uji paired-samples t test dan uji Kruskal-Wallis. Uji Wilcoxon untuk data tidak normal. Uji korelasi menggunakan pearson untuk yang normal dan spearman untuk data tidak normal.

Hasil : Yoghurt kedelai hitam dengan dosis $115 \mathrm{ml}$ dan $225 \mathrm{ml}$ terbukti menurunkan kadar kolesterol LDL berturutturut sebesar $2.73 \%$ dan 0.099\% namun tidak bermakna secara statistik. Yoghurt kedelai hitam dengan dosis 225 ml meningkatkan kadar kolesterol HDL secara bermakna sebesar 10.26\%. Yoghurt kedelai hitam dengan dosis 115 ml menurunkan kadar kolesterol HDL sebesar $2.71 \%$.

Simpulan : Pemberian yoghurt kedelai hitam selama 21 hari dengan dosis $115 \mathrm{ml}$ dan $225 \mathrm{ml}$ dapat menurunkan kadar kolesterol LDL berturut-turut sebesar $2.73 \%$ dan $0.099 \%$ juga dapat meningkatkan kadar kolesterol HDL sebesar 10.26\%. Yoghurt kedelai hitam menurunkan kadar kolesterol HDL sebesar $2.71 \%$.
\end{abstract}

Kata Kunci : yoghurt kedelai hitam; kadar kolesterol HDL; kadar kolesterol LDL; dislipidemia

\section{PENDAHULUAN}

Dislipidemia merupakan salah satu faktor risiko penyakit kardiovaskuler yang ditandai dengan kenaikan kadar kolesterol total, kolesterol low density-lipoprotein (LDL), serta penurunan kolesterol high density-lipoprotein (HDL). ${ }^{1}$

${ }^{*}$ Penulis Penanggungjawab 
Kondisi ini dapat menyebabkan terjadinya penumpukan kolesterol pada dinding arteri yang akan menyebabkan proses aterosklerosis.

Penelitian tahun 2004 yang dilakukan di empat kota besar di Indonesia didapatkan keadaan dislipidemia berat (total kolesterol $\geq 240 \mathrm{mg} / \mathrm{dl}$ ) pada orang berusia diatas 55 tahun didapatkan sebanyak 52,2\% di Bandung, 27,7\% di Yogyakarta, sedangkan $56 \%$ di Padang dan Jakarta. $^{2}$ Dislipidemia berkaitan dengan penyakit jantung. Prevalensi nasional penyakit jantung adalah $7,2 \%$, Jawa Tengah merupakan salah satu provinsi yang memiliki prevalensi melebihi prevalensi nasional yaitu sebesar $8,4 \%{ }^{3}$

Kadar kolesterol yang tinggi merupakan faktor risiko penyakit kardiovaskular. ${ }^{4,5}$ Pengaturan pola makan dan modifikasi diet berperan penting dalam menurunkan kadar kolesterol darah. Salah satu diet yang dianjurkan yaitu mengkonsumsi jenis bahan makanan seperti kedelai sebagai alternatif yang efektif untuk menurunkan kadar kolesterol darah.

Meta-analisis dari 38 uji klinis menunjukkan bahwa konsumsi protein kedelai secara signifikan dapat menurunkan kadar kolesterol LDL dan meningkatkan kadar kolesterol HDL. ${ }^{6}$ Kedelai juga mengandung isoflavon dan anthosianin yang berfungsi sebagai antioksidan. Kedelai hitam (Glycine soja) memiliki kandungan anthosianin yang lebih tinggi dibandingkan dengan kedelai kuning (Glycine max). ${ }^{7}$ Kandungan isoflavon pada kedelai hitam dapat meningkatkan kadar kolesterol HDL dan menurunkan kadar kolesterol LDL dalam darah. ${ }^{8}$ Pengolahan kedelai hitam dalam bentuk fermentasi dapat meningkatkan aktivitas antioksidan menjadi lebih tinggi. Dalam proses ini, senyawa isoflavon mengalami hidrolisis sehingga menghasilkan senyawa isoflavon bebas disebut aglikon. ${ }^{9}$

Black soyghurt merupakan yoghurt yang terbuat dari susu kedelai hitam yang diasamkan melalui proses fermentasi dengan menggunakan campuran bakteri pembentuk asam. Soyghurt memiliki keunggulan dibandingkan yoghurt susu sapi karena kedelai hitam memiliki kemampuan antioksidan yang lebih tinggi untuk mencegah oksidasi lemak selain itu, hasil fermentasi susu kedelai hitam tidak mengandung laktosa maupun kolesterol sehinggga baik untuk kesehatan. Konsumsi soyghurt juga bermanfaat bagi keseimbangan ekosistem pada saluran intestinal dengan meningkatkan populasi probiotik dan menurunkan populasi bakteri patogen. ${ }^{10}$
Penelitian terdahulu yang dilakukan pada tikus Sprague Dawley hiperkolesterolemia, diperoleh hasil bahwa pemberian Black soyghurt sebanyak $2 \mathrm{ml}, 3 \mathrm{ml}$, dan $4 \mathrm{ml}$ selama 21 hari mampu menurunkan kadar kolesterol LDL secara signifikan. Penurunan kadar LDL paling bermakna terjadi pada kelompok perlakuan pemberian Black soyghurt $2 \mathrm{ml}$ dan $4 \mathrm{ml}$. Jika dosis ini dikonversikan sesuai kebutuhan manusia yang memiliki Berat Badan $70 \mathrm{~kg}$ maka diperoleh dosis $115 \mathrm{ml}$ dan 225, dosis ini didapatkan dari hasil kali konversi dosis pada tikus dengan bilangan konversi $56,0 .{ }^{11}$

Risiko terjadinya dislipidemia pada pria lebih besar daripada wanita karena pada wanita produktif terdapat efek perlindungan dari hormon estrogen, sementara hormon seks pria (testosteron) yang rendah mempercepat timbulnya aterosklerosis ${ }^{12}$ Pria usia 40 tahun keatas diketahui berisiko mengalami dislipidemia. ${ }^{13}$ Aktifitas fisik yang rendah merupakan salah satu dari faktor risiko yang dapat mengakibatkan dislipidemia. Alasan pemilihan responden penelitian karyawan Setda Provinsi Jawa Tengah adalah untuk mewakili kelompok dengan aktivitas fisik ringan. Berdasarkan uraian tersebut maka peneliti berkeinginan melakukan uji pemberian Black soyghurt pada karyawan kantor Setda Provinsi Jawa Tengah yang menderita dislipidemia.

\section{METODE PENELITIAN}

Penelitian ini adalah penelitian true experimental dengan rancangan control group pretest-post-test. Variabel terikat dalam penelitian ini adalah kadar kolesterol LDL dan kadar kolesterol HDL penderita dislipidemia, sedangkan variabel bebas dalam penelitian ini adalah dosis Black soyghurt.

Subjek penelitian adalah karyawan kantor Sekretariat Daerah Provinsi Jawa Tengah, dengan kriteria inklusi memiliki kadar kolesterol LDL $\geq$ 100 mg/dl, kadar kolesterol HDL < 40 mg/dl, tidak sedang mengkonsumsi obat-obatan antidislipidemia selama penelitian, jenis kelamin laki-laki, berumur 40 - 65 tahun, merokok tidak lebih dari 10 batang/hari, tidak mengkonsumsi alkohol, tidak mengkonsumsi kopi, tidak dalam keadaan sakit atau dalam perawatan dokter berkaitan dengan penyakit jantung koroner, diabetes mellitus, hipertensi, gagal ginjal dan penyakit kronik lainnya. Perhitungan subyek penelitian menggunakan rumus uji hipotesis 
terhadap rerata dua populasi independen dan dibutuhkan sebanyak 42 subyek.

Penentuan subyek penelitian menggunakan metode consecutive sampling. Sebanyak 100 orang bersedia diambil darahnya untuk proses skrining awal dan diperoleh sebanyak 42 orang yang memenuhi kriteria inklusi untuk menjadi subyek penelitian. Subyek dibagi menjadi 3 kelompok dengan metode simple random sampling, yang terdiri atas satu kelompok kontrol dan dua kelompok perlakuan, masing-masing kelompok terdiri atas 14 subyek. Kelompok perlakuan pertama mendapatkan Black soyghurt sebanyak $115 \mathrm{ml}$ dan kelompok perlakuan kedua mendapatkan Black soyghurt sebanyak $225 \mathrm{ml}$ selama 21 hari sedangkan kelompok kontrol tidak mendapatkan Black soyghurt. Asupan makan sehari-hari ketiga kelompok dikontrol sesuai dengan anjuran dan konseling yang telah diberikan. Catatan asupan makan dilakukan sebelum dan selama intervensi 21 hari. Sementara kepatuhan mengkonsumsi Black soyghurt dikontrol dengan menggunakan formulir daya terima. Pada hari ke-22 dilakukan kembali pemeriksaan kadar kolesterol LDL dan HDL. Pengukuran kadar kolesterol darah dilakukan oleh laboratorium "Permata" menggunakan metode Phosphotungistic precipilation. Kadar kolesterol LDL dihitung dengan rumus Friedewald. Darah diambil oleh petugas laboratorium setelah subyek berpuasa selama \pm 10 jam. Sementara data asupan makan subyek dianalisis menggunakan program nutrisurvey 2005.

Data yang telah ada diuji normalitasnya dengan uji Shapiro-Wilk. Analisis deskriptif digunakan untuk melihat gambaran karakteristik subjek serta asupan makan subjek selama penelitian. Perbedaan kadar kolesterol LDL sebelum dan sesudah perlakuan diuji dengan paired t-test. Perbedaan kadar kolesterol HDL menggunakan uji paired t-test untuk data kelompok kontrol dan perlakuan 2 dan uji Wilcoxon untuk data pada kelompok 1 karena data tidak normal. Perbedaan pengaruh konsumsi Black soyghurt terhadap kadar kolesterol LDL dianalisis menggunakan uji ANOVA, sementara terhadap kadar kolesterol HDL dianalisis dengan menggunakan uji Kruskal-Wallis. Hubungan antara asupan makan selama intervensi terhadap kadar kolesterol LDL dan HDL menggunakan uji pearson dan spearman untuk data yang tidak normal.

\section{HASIL PENELITIAN \\ Karakteristik Subyek}

Gambaran umur dan status gizi subyek sebelum penelitian disajikan dalam tabel 1.

Tabel 1. Karakteristik Subyek Penelitian

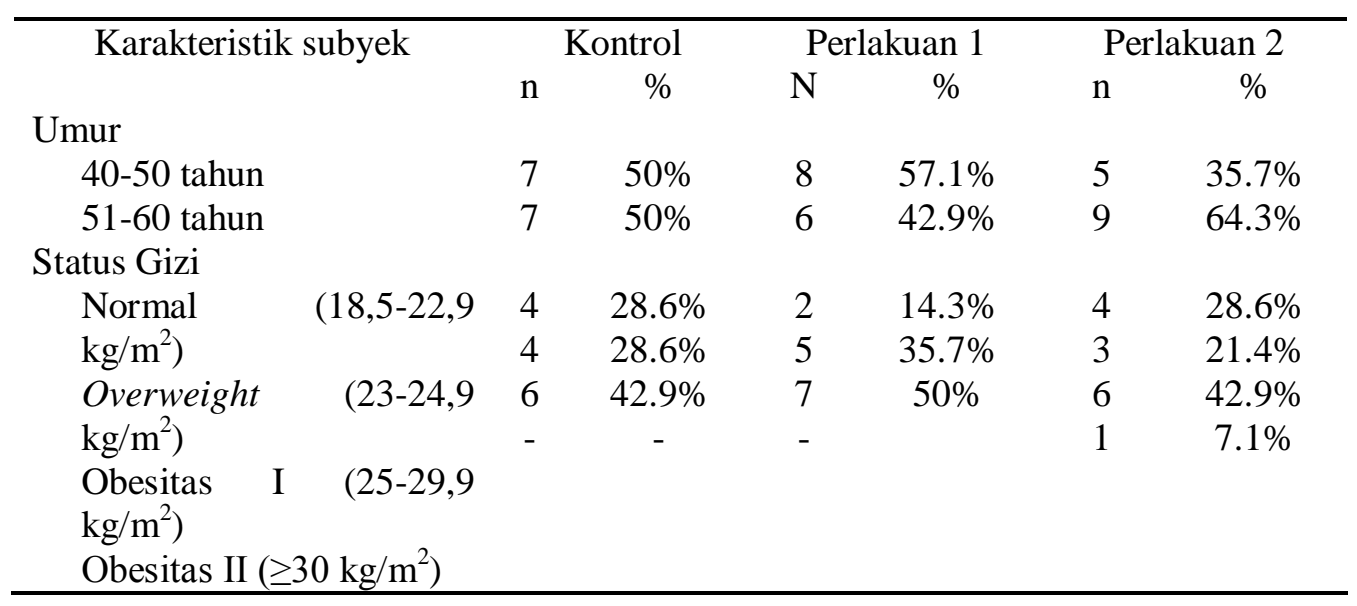

Tabel 1 menunjukkan subjek sebagian besar berada pada kelompok umur 51-60 tahun (52.4\%), dan sebagian besar memiliki kategori status gizi Overweight dan Obesitas I (73.8\%).

\section{Keadaan Subjek penelitian pada awal penelitian}

Keadaan subyek penelitian disajikan untuk mengetahui homogenitas variabel pada ketiga kelompok.

Tabel 2. Keadaan Subjek penelitian pada awal penelitian

\begin{tabular}{lllll}
\hline Variabel & Kontrol & Perlakuan I & Perlakuan II & $\mathrm{P}^{\mathrm{a}}$ \\
\hline
\end{tabular}




\begin{tabular}{lcccc}
\hline & $(\mathrm{n}=14)$ & $(\mathrm{n}=14)$ & $(\mathrm{n}=14)$ & \\
& mean $\pm \mathrm{SD}$ & mean $\pm \mathrm{SD}$ & mean $\pm \mathrm{SD}$ & \\
\hline Usia(tahun) & $49.29 \pm 4.668$ & $49.07 \pm 4.65$ & $50.43 \pm 4.59$ & 0.709 \\
IMTawal $\left(\mathrm{kg} / \mathrm{m}^{2}\right)$ & $24.98 \pm 2.71$ & $25.17 \pm 2.21$ & $25.65 \pm 4.29$ & 0.852 \\
LDL awal $(\mathrm{mg} / \mathrm{dl})$ & $156.70 \pm 34.06$ & $145.36 \pm 17.07$ & $133.6 \pm 23.86$ & 0.075 \\
HDL awal $(\mathrm{mg} / \mathrm{dl})$ & $36.43 \pm 5.97$ & $39.93 \pm 4.78$ & $36.36 \pm 4.03$ & 0.109 \\
\hline
\end{tabular}

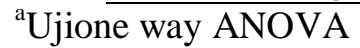

Tabel 2 menunjukkan tidak ada perbedaan usia, IMT awal, kadar kolesterol LDL, dan kadar kolesterol HDL pada ketiga kelompok sebelum dilakukan intervensi ( $p>0.05)$.

\section{Asupan makan sebelum dan selama intervensi}

Asupan makan sebelumdan selama intervensi disajikan untuk mengetahui perubahan asupan yang terjadi pada subyek penelitian.

Tabel 3. Asupan makan sebelum dan selama intervensi

\begin{tabular}{lcccc}
\hline \multicolumn{1}{c}{ Variabel } & $\begin{array}{c}\text { Kontrol } \\
(\mathrm{n}=14) \\
\text { mean } \pm \mathrm{SD}\end{array}$ & $\begin{array}{c}\text { Perlakuan } 1 \\
(\mathrm{n}=14) \\
\text { mean } \pm \mathrm{SD}\end{array}$ & $\begin{array}{c}\text { Perlakuan } 2 \\
(\mathrm{n}=14) \\
\text { mean } \pm \mathrm{SD}\end{array}$ & $\mathrm{P}$ \\
\hline Energi pre(kkal) & $1055.04 \pm 263.83$ & $1268.7 \pm 454.77$ & $1337.74 \pm 363.86$ & $0.121^{\mathrm{a}}$ \\
Energi & $937.02 \pm 202.82$ & $927.20 \pm 234.72$ & $1055.32 \pm 240.57$ & $0.262^{\mathrm{a}}$ \\
durante(kkal) & $40.52 \pm 9.73$ & $50.39 \pm 16.86$ & $51.95 \pm 16.97$ & $0.102^{\mathrm{a}}$ \\
Protein pre $(\mathrm{g})$ & $38.36 \pm 8.58$ & $39.56 \pm 22.08$ & $40.38 \pm 11.65$ & $0.940^{\mathrm{a}}$ \\
Protein durante(g) & $34.53 \pm 15.32$ & $48.21 \pm 21.14$ & $43.18 \pm 17.43$ & $0.143^{\mathrm{a}}$ \\
Lemak pre(g) & $28.59 \pm 10.87$ & $30.46 \pm 9.32$ & $35.11 \pm 8.84$ & $0.201^{\mathrm{a}}$ \\
Lemak durante(g) & $150.83 \pm 38.15$ & $160.02 \pm 58.00$ & $188.65 \pm 59.22$ & $0.154^{\mathrm{a}}$ \\
KHpre(g) & $129.85 \pm 22.72$ & $132.97 \pm 36.86$ & $151.27 \pm 35.68$ & $0.181^{\mathrm{a}}$ \\
KH durante(g) & $238.33 \pm 213.52$ & $328.91 \pm 359.10$ & $246.29 \pm 192.88$ & $0.943^{\mathrm{b}}$ \\
Koles.pre(mg) & $152.59 \pm 114.51$ & $139.69 \pm 100.36$ & $149.74 \pm 100.20$ & $0.944^{\mathrm{a}}$ \\
Koles. durante(mg) & $9.29 \pm 3.71$ & $7.81 \pm 3.32$ & $12.01 \pm 2.77$ & $0.006^{\mathrm{a}^{\mathrm{a}}}$ \\
Serat pre(g) & $7.65 \pm 4.62$ & $11.17 \pm 3.90$ & $10.61 \pm 3.21$ & $0.051^{\mathrm{a}}$ \\
Serat durante(g) & & & & \\
\hline
\end{tabular}

${ }^{a}$ Ujione way ANOVA *beda bermakna

${ }^{\mathrm{b}}$ Uji Kruskal-Wallis

Tabel 3 menunjukkan tidak terdapat perbedaan asupan energi, karbohidrat, protein, lemak, dan kolesterol antara ketiga kelompok pada awal penelitian dan selama penelitian $(p>0.05)$. Namun terdapat perbedaan asupan serat antara ketiga kelompok pada awal penelitian $(p<0.05)$.
Korelasi kadar kolesterol LDL akhir dengan asupan selama intervensi kelompok kontrol

Hubungan antara kadar kolesterol LDL akhir dengan asupan makan selama intervensi ditampilkan pada tabel dibawah ini.

Tabel 4. Korelasi kadar kolesterol LDL akhir dengan asupan selama intervensi

\begin{tabular}{cccccccc}
\hline Kadar & & Energi & Protein & Lemak & KH & Kolesterol & Serat \\
kolest.LDL & & & & & & & \\
& $\mathrm{r}$ & -0.628 & -0.075 & -0.281 & -0.525 & -0.137 & 0.170 \\
& $\mathrm{p}$ & 0.016 & 0.799 & 0.331 & 0.054 & 0.640 & 0.561 \\
\hline
\end{tabular}

*Uji Korelasi Pearson

Tabel 4 menunjukkan kekuatan korelasi antara penurunan kadar kolesterol LDL dengan peningkatan asupan energi masuk dalam kategori kuat yaitu $r$ sebesar
-0.628. Terdapat hubungan yang signifikan antara penurunan kadar kolesterol LDL dengan asupan energi selama intervensi. Berdasarkan adjusted $R$ square didapatkan $34.3 \%$ yang artinya persamaan 
yang diperoleh mampu menjelaskan penurunan kadar kolesterol LDL sebesar 34.3\%.

Korelasi kadar kolesterol HDL akhir dengan asupan selama intervensi kelopok perlakuan I
Hubungan antara kadar kolesterol HDL akhir dengan asupan makan selama intervensi ditampilkan pada tabel dibawah ini.

Tabel 5. Korelasi kadar kolesterol HDL akhir dengan asupan selama intervensi

\begin{tabular}{llllllll}
\hline Kadar & & Energi & Protein & Lemak & KH & Kolesterol & Serat \\
Kolest.HDL & & & & & & & \\
& $\mathrm{r}$ & -0.071 & 0.059 & 0.047 & -0.022 & -0.376 & -0.013 \\
& $\mathrm{p}$ & 0.809 & 0.841 & 0.874 & 0.940 & 0.185 & 0.964 \\
\hline
\end{tabular}

*Uji Korelasi Spearman

Tabel 5 menunjukkan terdapat hubungan yang signifikan antara penurunan kadar kolesterol HDL dengan peningkatan asupan kolesterol pada kelompok perlakuan I, namun kekuatan korelasi tergolong lemah.

\section{Perbedaan Perubahan Asupan makan antar kelompok}

Perbedaan perubahan asupan makandapat dilihat pada tabel di bawah ini.

Tabel 6. Perbedaan perubahan asupan sebelum dan selama intervensi

\begin{tabular}{lcccc}
\hline \multicolumn{1}{c}{ Variabel } & Kontrol & PerlakuanI & Perlakuan II & $\mathrm{p}$ \\
& $\mathrm{n}=14$ & $\mathrm{n}=14$ & $\mathrm{n}=14$ & \\
$\Delta$ Asupan E(kkal) & $-118.02 \pm 226.51$ & $-341.53 \pm 330.81$ & $-282.42 \pm 252.18$ & $0.094^{\mathrm{a}}$ \\
$\Delta$ Asupan KH(g) & $-20.98 \pm 27.91$ & $-27.06 \pm 40.73$ & $-25.63(-113.33-1.58)$ & $0.552^{\mathrm{b}}$ \\
$\Delta$ Asupan L(g) & $-5.93 \pm 16.22$ & $-17.75 \pm 17.44$ & $-8.06 \pm 14.99$ & $0.135^{\mathrm{a}}$ \\
$\Delta$ Asupan P(g) & $-2.16 \pm 10.58$ & $-12.07(-43.44-79.15)$ & $-11.57 \pm 13.53$ & $0.049^{\mathrm{b}}$ \\
& & & & ${ }^{*}$ \\
$\Delta$ Asupan serat $(\mathrm{g})$ & $-2.35 \pm 16.84$ & $3.36 \pm 4.13$ & $-1.4 \pm 3.70$ & ${ }^{*} .001^{\mathrm{a}}$ \\
& & & & \\
$\Delta$ Asupan & $-85.73 \pm 172.54$ & $-47.27(-10.250-$ & $-96.55 \pm 164.40$ & $0.817^{\mathrm{b}}$ \\
Koles.(mg) & & $166.87)$ & & \\
\hline
\end{tabular}

${ }^{a}:$ Uji one way ANOVA ${ }^{\text {b}}$ : Uji Kruskal-wallis *beda bermakna

Tabel 6 menunjukkan adanya perbedaan perubahan asupan serat dan protein antar ketiga kelompok $(\mathrm{p}<0.05)$ namun tidak ada perbedaan perubahan asupan energi, karbohidrat, lemak, protein dan kolesterol ( $\mathrm{p}>0.05)$.
Berdasarkan uji one way ANOVA terdapat perbedaan asupan serat sehingga dilakukan uji lanjut Post-Hoc untuk melihat perbedaan rerata asupan serat antar kelompok.

Tabel 7. Hasil analisis perubahan asupan serat sebelum dan selama intervensi

\begin{tabular}{ccccc}
\hline Uji Post-hoc & Perbedaan & \multicolumn{2}{c}{ IK95\% } & P* \\
& rerata & minimum & maximum & \\
\hline Kontrol vs perlakuan I & -4.997 & -7.878 & -2.115 & 0.001 \\
Kontrol vs perlakuan II & -0.237 & -3.119 & 2.643 & 0.868 \\
Perlakuan I vs perlakuan & 4.759 & 1.878 & 7.640 & 0.002 \\
$\quad$ II & & & & \\
\hline
\end{tabular}

*uji

Tabel 7 menunjukkan, adanya perbedaan rerata asupan serat yang signifikan terjadi antara kelompok kontrol dan perlakuan I (-4.997) serta antara kelompok perlakuan I dan perlakuan II (4.759) dengan $(\mathrm{p}<0.05)$.

Tabel 8. Hasil analisis perubahan asupan protein 


\begin{tabular}{cccc}
\hline Kelompok & $\mathrm{N}$ & $\begin{array}{c}\text { Perubahan Asupan } \\
\text { protein }\end{array}$ & $\mathrm{P}$ \\
Kontrol & 14 & $-2.16 \pm 10.58$ & 0.085 \\
Perlakuan I & 14 & $-12.07(-43.44-79.15)$ & 0.016 \\
Perlakuan II & 14 & $-11.57 \pm 13.53$ & 0.679 \\
\hline
\end{tabular}

Uji Kruskal-Wallis. Uji post-hoc Mann-Whitney: kontrol vs perlakuan II p=0.085; kontrol vs perlakuan I $\mathrm{p}=0.016$; perlakuan I vs perlakuan II $\mathrm{p}=0.679$

Tabel 8 menunjukkan, perubahan asupan protein yang signifikan selama intervensi terjadi pada kelompok perlakuan I.

Pengaruh konsumsi Black soyghurt terhadap kadar kolesterol LDL dan HDL

Tabel 9. Pengaruh pemberian Black soyghurt terhadap kadar kolesterol LDL antar kelompok sebelum dan sesudah intervensi

\begin{tabular}{cccccc}
\hline Kelompok & $\begin{array}{c}\text { Sebelum } \\
(\mathbf{m g} / \mathbf{d l}) \\
\text { mean } \mathbf{\text { SD }}\end{array}$ & $\begin{array}{c}\text { Sesudah } \\
(\mathbf{m g} / \mathbf{d l}) \\
\text { mean } \pm \text { SD }\end{array}$ & $\begin{array}{c}\Delta \\
(\mathbf{m g} / \mathbf{d l}) \\
\text { mean } \pm \text { SD }\end{array}$ & $\begin{array}{c}\Delta \\
\text { \% }\end{array}$ & $\mathbf{P}^{*}$ \\
\hline Kontrol & $156.70 \pm 34.06$ & $151.58 \pm 33.11$ & $5.13 \pm 13.72$ & 3.16 & 0.186 \\
Perlakuan 1 & $145.36 \pm 17.07$ & $140.86 \pm 27.59$ & $4.51 \pm 18.39$ & 2.73 & 0.376 \\
Perlakuan 2 & $133.6 \pm 23.86$ & $132.91 \pm 32.41$ & $0.69 \pm 26.3$ & 0.099 & 0.924 \\
\hline
\end{tabular}

* Uji Paired t test

Tabel 9 menunjukkan secara statistik tidak ada perbedaan kadar kolesterol LDL sebelum dan setelah intervensi pada ketiga kelompok ( $p>0.05$ ). Namun, secara deskriptif terdapat penurunan kadar kolesterol LDL pada ketiga kelompok, di mana penurunan terbesar terjadi pada kelompok kontrol $(5.13 \pm 13.72)$.

Pengaruh pemberian Black soyghurt terhadap kadar kolesterol HDL disajikan pada tabel 10 .

Tabel 10. Pengaruh pemberian Black soyghurt terhadap kadar kolesterol HDL antar kelompok sebelum dan sesudah intervensi

Jji paired $t$ test

\begin{tabular}{cccccc}
\hline Kelompok & $\begin{array}{c}\text { Sebelum } \\
(\mathbf{m g} / \mathbf{d l})\end{array}$ & $\begin{array}{c}\text { Sesudah } \\
(\mathbf{m g} / \mathbf{d l})\end{array}$ & $\begin{array}{c}\Delta \\
(\mathbf{m g} / \mathbf{d l})\end{array}$ & $\begin{array}{c}\Delta \\
\text { \% }\end{array}$ & $\mathbf{P}$ \\
\hline Kontrol & $36.43 \pm 5.97$ & $37.57 \pm 5.58$ & $1.14 \pm 4.47$ & 4.11 & $0.356^{\mathrm{a}}$ \\
Perlakuan 1 & $39.93 \pm 4.78$ & $38(31-66)$ & $-1(-13-32)$ & -2.71 & $0.448^{\mathrm{b}}$ \\
Perlakuan 2 & $36.36 \pm 4.03$ & $40.14 \pm 39.50$ & $3.78 \pm 6.00$ & 10.26 & $0.035^{\mathrm{a}}$ \\
\hline
\end{tabular}

${ }^{\mathrm{b}} \mathrm{Uji}$ Wilcoxon

Tabel 10 menunjukkan peningkatan kadar kolesterol HDL terjadi pada kelompok kontrol dan perlakuan II, di mana peningkatan terbesar terjadi pada kelompok perlakuan II. Sementara pada perlakuan I terjadi penurunan kadar kolesterol HDL. Secara statistik, terdapat perbedaan kadar kolesterol HDL yang bermakna pada kelompok perlakuan II $(\mathrm{p}<0.05)$, namun pada kelompok kontrol dan perlakuan I perbedaan tersebut tidak bermakna $(\mathrm{p}>0.05)$.

Pengaruh konsumsi Black soyghurt terhadap rerata perubahan kolesterol LDL dan HDL

Pengaruh konsumsi Black soyghurt terhadap rerata perubahan kolesterol LDL dan HDL antar ketiga kelompok disajikan pada tabel 11 .

Tabel 11. Perbedaan rerata perubahan kolesterol LDL dan HDL antar ketiga kelompok

\begin{tabular}{ccccc}
\hline$\Delta(\mathbf{m g} / \mathbf{d l})$ & Kontrol & Perlakuan 1 & Perlakuan 2 & P \\
\hline$\Delta$ Kol. LDL & $5.13 \pm 13.72$ & $4.51 \pm 18.39$ & $0.69 \pm 26.3$ & $0.820^{\mathrm{a}}$ \\
$\Delta$ Kol. HDL & $1.14 \pm 4.47$ & $-1(-13-32)$ & $3.78 \pm 6.00$ & $0.125^{\mathrm{b}}$ \\
\hline
\end{tabular}

${ }^{a}$ Uji one way ANOVA 
${ }^{\mathrm{b}}$ Uji Kruskal-Wallis

Tabel 11 menunjukkan tidak ada perbedaan pengaruh pemberian Black soyghurt terhadap kolesterol LDL dan kolesterol HDL antara ketiga kelompok ( $\mathrm{p}>0.05)$. Pengaruh Black soyghurt terhadap kelompok perlakuan ditampilkan pada tabel 12 .

Tabel 12.Perbedaan rerata perubahan kolesterol LDL dan HDL antar kelompok perlakuan

\begin{tabular}{cccc}
\hline$\Delta(\mathbf{m g} / \mathbf{d l})$ & Perlakuan 1 & Perlakuan 2 & P \\
\hline$\Delta$ Kol. LDL & $4.51 \pm 18.39$ & $0.69 \pm 26.3$ & $0.660^{\mathrm{a}}$ \\
$\Delta$ Kol. HDL & $-1(-13-32)$ & $3.78 \pm 6.00$ & $0.05^{\mathrm{b}}$ \\
\hline
\end{tabular}

${ }^{a}$ Uji Independent $t$ test

${ }^{\mathrm{b}}$ Mann-Whitney

Tabel 12 menunjukkan tidak ada perbedaan perubahan kolesterol LDL dan kolesterol HDL yang bermakna antar kelompok perlakuan I dan II ( $>>0.05)$. Hal ini menunjukkan bahwa secara statistik, pemberian Black soyghurt dengan dosis $115 \mathrm{ml}$ dan $225 \mathrm{ml}$ memberikan pengaruh yang sama terhadap penurunan kolesterol LDL dan peningkatan kolesterol HDL pada kedua kelompok.

\section{PEMBAHASAN}

Pemberian black soyghurt dengan dosis $115 \mathrm{ml}$ dan $225 \mathrm{ml}$ selama 21 hari dapat menurunkan kadar kolesterol LDL berturut-turut sebesar $2.73 \%$ dan $0.099 \%$ namun penurunan ini tidak bermakna secara statistik. Sementara pengaruh pemberian black soyghurt terhadap peningkatan kadar kolesterol HDL secara bermakna hanya terjadi pada kelompok II sebesar $10.26 \%$. pada kelompok perlakuan I justru mengalami penurunan sebesar $2.71 \%$.

Karateristik subjek dalam penelitian ini adalah pria dislipidemia yang sebagian besar berada pada kelompok umur 51-60 tahun (64.3\%). Sebagian besar memiliki kategori status gizi Overweight dan obesitas I (73.8\%). Namun secara keseluruhan tidak ada perbedaan umur maupun status gizi antar ketiga kelompok, begitu pula dengan kadar kolesterol LDL dan kadar kolesterol HDL sebelum intervensi. Sehingga dapat disimpulkan karateristik subjek pada awal penelitian tergolong homogen.

Gangguan metabolisme lipoprotein sering terjadi pada penderita overweight dan obesitas yang menyebabkan terjadinya peningkatan kadar kolesterol LDL dan penurunan kadar kolesterol HDL. ${ }^{14}$ Subjek dislipidemia yang sebagian besar berada pada kelompok usia 51-60 tahun dalam penelitian ini sejalan dengan penelitian yang dilakukan di Pakistan, bahwa risiko dislipidemia pada pria meningkat seiring dengan bertambahnya usia, ${ }^{15}$ hal ini disebabkan karena adanya penurunan hormon testosteron yang dapat meningkatkan risiko dislipidemia. ${ }^{16}$ Selain itu,penelitian yang dilakukan terhadap pria lanjut usia di Australia menyatakan bahwa rendahnya kadar hormon testosteron berkaitan dengan risiko penyakit stroke. $^{17}$

Gambaran asupan makan subjek antara ketiga kelompok pada awal penelitian dan selama penelitian tidak ada perbedaan yang bermakna kecuali pada asupan serat dan asupan protein. Asupan serat tertinggi berada pada kelompok perlakuan II yaitu sebesar $12.01 \pm 2.77 \mathrm{~g}$ dan terendah pada perlakuan I yaitu $7.81 \pm 3.32 \mathrm{~g}$. American Dietetic Association (ADA) menganjurkan konsumsi serat sebanyak 20-35 $\mathrm{g} /$ hari atau setara dengan $14 \mathrm{~g} / 1000$ kkal. Sementara asupan serat tersebut masih belum memenuhi angka yang dianjurkan. Asupan serat yang rendah berkaitan dengan peningkatan kadar kolesterol LDL. ${ }^{18}$ Perbedaan asupan protein sebelum dan selama intervensi yang bermakna terjadi pada kelompok perlakuan II dimana selama intervensi terjadi penurunan asupan sebesar $11.57 \pm 13.53$ g. Berdasarkan sumbernya, protein terdiri atas protein hewani dan protein nabati. Sumber protein hewani cenderung mengandung asam lemak jenuh dan asam lemak tidak jenuh tunggal sedangkan sumber protein nabati mengandung asam lemak tidak jenuh tunggal dan tidak jenuh ganda. Asam lemak tidak jenuh dapat menurunkan kadar kolesterol LDL dan meningkatkan kadar kolesterol HDL sedangkan asam lemak jenuh memiliki efek sebaliknya. ${ }^{19}$

Setelah pemberian black soyghurt selama 21 hari terjadi penurunan kadar kolesterol LDL sebesar $2.73 \%$ pada kelompok perlakuan I dengan dosis $115 \mathrm{ml}$ dan $0.099 \%$ pada kelompok perlakuan II dengan dosis $225 \mathrm{ml}$. Penurunan 
kadar kolesterol LDL juga terjadi pada kelompok kontrol sebesar $3.16 \%$.

Black soyghurt merupakan yoghurt yang terbuat dari susu kedelai hitam yang diasamkan melalui proses fermentasi dengan menggunakan campuran bakteri pembentuk asam. Kedelai hitam mengandung anthosianin dan isoflavon yang merupakan jenis antioksidan. Isoflavon yang terkandung dalam kedelai merupakan sterol yang berasal dari tumbuhan (fitosterol) yang jika dikonsumsi dapat menghambat absorbsi kolesterol baik yang berasal dari diet maupun kolesterol yang diproduksi dari hati. Hambatan ini terjadi karena fitosterol berkompetisi dan menggantikaan posisi kolesterol dalam micelle. Adanya mekanisme tersebut, maka kolesterol yang terserap oleh usus juga sedikit sehingga pembentukan kilomikron dan VLDL juga terhambat sehingga kadar LDL turun. $^{20}$

Anthosianin merupakan salah satu senyawa flavonoid yang merupakan komponen utama warna hitam pada kulit kedelai hitam. Flavonoid dapat menurunkan kadar kolesterol LDL dengan menghambat penyerapan kolesterol, meningkatkan eksresi empedu, dan dapat menghambat aktifitas enzim 3-hidroksi-3metilglutaril $\mathrm{CoA}(\mathrm{HMG}-\mathrm{KoA})$ yang berperan dalam penghambatan sintesis kolesterol serta enzim asil CoA yang berperan dalam penurunan esterifikasi kolesterol pada usus dan hati. Selain itu, flavonoid juga memiliki sifat lipofilik yang mampu mengikat kolesterol LDL. ${ }^{21}$

Penurunan kadar kolesterol LDL pada kelompok kontrol lebih besar dibandingkan dengan kelompok perlakuan I dan II. Hasil uji korelasi variabel perancu menunjukkan asupan energi selama intervensi memberikan pengaruh yang signifikan terhadap kadar kolesterol LDL akhir pada kelompok kontrol, sedangkan asupan protein, lemak, karbohidrat, kolesterol, dan serat tidak memberikan pengaruh yang signifikan. Variabel asupan energi memiliki korelasi negatif yang kuat sebesar -0.628 terhadap kadar kolesterol LDL akhir dengan adjusted $R$ square $34.3 \%$.

Proses fermentasi kedelai hitam menjadi Black soyghurt dapat menyebabkan hidrolisis senyawa isoflavon menjadi bentuk bebas yaitu aglikon dengan aktifitas antioksidan yang lebih tinggi. Black soyghurt juga mengandung bakteri asam laktat yang dapat menyebabkan terjadinya penurunan kolesterol. Bakteri asam laktat dapat mendegradasi kolesterol menjadi coprostanol yaitu sebuah sterol yang tidak dapat diserap oleh usus. Selanjutnya coprostanol dan sisa kolesterol dikeluarkan bersama- sama tinja, dengan demikian jumlah kolesterol yang diserap tubuh menjadi rendah. ${ }^{22}$

Pengaruh perlakuan terhadap kadar kolesterol HDL diperoleh hasil bahwa peningkatan kadar kolesterol HDL terjadi pada kelompok kontrol sebesar $4.11 \%$ dan perlakuan II sebesar $10.26 \%$. Sedangkan pada kelompok perlakuan I terjadi penurunan kadar kolesterol HDL sebesar $2.71 \%$.

Salah satu mekanisme peningkatan kadar kolesterol HDL adalah melalui peningkatan jumlah apolipoprotein A-1 yang merupakan prekusor pembentukan HDL. Flavonoid yang terkandung dalam kedelai hitam dapat meningkatkan jumlah apolipoprotein A-1. Apolipoprotein A-1 bertugas sebagai kofaktor enzim untuk LCAT serta sebagai ligand untuk interaksi dengan reseptor lipoprotein dalam jaringan pada HDL. Dengan adanya peningkatan apolipoprotein A-1 diharapkan dapat meningkatkan kadar kolesterol HDL. HDL yang mengandung Apolipoprotein A-1 bersifat protektif terhadap aterosklerosis. ${ }^{23}$

Penurunan kadar kolesterol HDL dapat disebabkan karena beberapa faktor, diantaranya kebiasaan merokok, rendahnya aktifitas fisik, asupan karbohidrat yang tinggi dan penggunaan obat-obatan, namun sudah dilakukan pengontrolan terhadap faktor-faktor tersebut kecuali faktor aktifitas fisik yang rendah. Rendahnya aktifitas fisik (<30 menit) dalam seminggu dapat meningkatkan risiko penurunan kadar kolesterol HDL. $^{24}$

Hasil uji korelasi variabel perancu menunjukkan asupan kolesterol selama intervensi memberikan pengaruh yang signifikan terhadap kadar kolesterol HDL akhir pada kelompok perlakuan I. Variabel asupan kolesterol memiliki korelasi negatif yang lemah sebesar -0.376 terhadap kadar kolesterol HDL akhir dengan adjusted $R$ square $1 \%$.

\section{KETERBATASAN PENELITIAN}

Keterbatasan penelitian ini adalah tidak dilakukan uji kandungan zat bioaktif seperti anthosianin dan isoflavon pada kedelai hitam. Selain itu, penelitian ini juga dilakukan pada saat bulan puasa dan tidak dilakukan pengontrolan aktifitas fisik.

\section{SIMPULAN}

Pemberian black soyghurt selama tiga minggu dapat menurunkan kadar kolesterol LDL, 
namun penurunan ini tidak bermakna secara statistik. Sementara pengaruh pemberian black soyghurt terhadap peningkatan kadar kolesterol HDL secara bermakna hanya terjadi pada kelompok II sebesar. Kadar kolesterol HDL pada kelompok perlakuan I justru mengalami penurunan sebesar. Pada kelompok kontrol terjadi penurunan kadar kolesterol LDL dan terjadi peningkatan kadar kolesterol HDL.

\section{SARAN}

1. Penelitian lebih lanjut perlu dilakukan dengan subyek penelitian tidak hanya pada pria dislipidemia, sehingga peran black soyghurt dalam menurunkan kolesterol dapat dimanfaatkan secara umum.

2. Perlu dilakukan wawancara kembali untuk mengetahui aktifitas subjek selama intervensi karena aktifitas fisik memiliki pengaruh yang besar terhadap perubahan kadar kolesterol HDL.

\section{DAFTAR PUSTAKA}

1. Adam JMF, Dislipidemia. Dalam: Sudoyo AW, Setiyohadi B, Alwi I, K. Marcellus S, Setiati S. Ilmu Penyakit Dalam. Edisi V Jilid III. Jakarta: InternaPublishing; 2009.hal.1984;92.

2. Kamso S, Purwantiyastuti, Juwita R. Dislipidemia pada lanjut usiadi kota Padang.Makara , kesehatan, vol 6, no.2. desember 2002.

3. Laporan Riset Kesehatan Dasar.2007

4. Kuklina EV, Yoon WP, Keenan NL. Prevalence of Coronary Heart Disease Risk Factors and Screening for High Cholesterol Level Among Young Adults, United States, 1999 - 2006. Ann Fam Med 2010;8:327 - 333.

5. Smith W. Nutrition and your health : Lipids dan cardiovaskuler disease. In contemporary nutrition. $7^{\text {th }}$ Edition. New York : 2009.; 191-195.

6. Anderson JW, Johnstone BM, Cook-Newell ME. Meta-analysis of the effects of soy protein intake on serum lipids. N Engl J Med 1995;333:276-2.

7. Ponnusha BS, Subramaniyam S, Pasupathi P, Subramaniyam B, Virumandy R. Antioxidant and Antimicrobial properties of Glycine Max-A review. Int J cur Bio Med Sci. 2011; 1(2): 49 - 62

8. Michihiro S. Soy in health and disease prevention. New York: Taylor and Francis Group; 2006.

9. Corinna RE, Sabine KE. Antioxidant Activity of Isoflavones and Their Major Metabolites Using Different in Vitro Assays. J. Agric. Food Chem, 2006; 54(8): 2926-2931.

10. Chien HL, Huang HY, Chou CC.Transformation of isoflavonephytoestrogens during the fermentation of soymilk with lactic acid bacteria and bifidobacteria.Food Microbiol.2006.23: 772-8

11. Riyanto S. Pengaruh pemberian yoghurt kedelai hitam (black soyghurt) terhadap profil lipid tikus hiperkolesterolemia. Artikel Ilmiah Mahasiswa Program Studi Ilmu Gizi. FK Undip Semarang; 2011.

12. Anwar TB. Dislipidemia Sebagai Faktor Risiko Penyakit Jantung Koroner. Artikel Ilmiah Mahasiswa Kedokteran Umum. FK USU Medan;2004.

13. Alberta Medical Association. Building Healthy Lifestyles Vascular Protection Dyslipidemia Clinical Guidence : 2006.

14. Howard BV, Ruotolo G, Robbins DC. Endocrinology and metabolism Clinics of North America. 2003, 32(4):855-867.

15. Humayun A, Shan AS, Alam S, Husein $H$. Relationship of Body mass index and Dyslipidemia in Different age groups of male and female population of Peshawar. J Ayub Med Coll Abbottabad. 2009; 21(2)

16. Haring R, Baumeister SE, Volzke H, Dorr M, Felix SB, Kroemer HK, et al. European Journal of Cardiovaskular Prevention \& Rehabilitation. 2011, 18(1):86-96

17. Yeap BB, Hyde Z, Almeida OP, Norman PE, Chubb P, Jamrozik K. et al. Lower testosterone levels predict incident stroke and transient Ischemic Attack In older men. J Clin Endocrinol metab.2009.94 : 2353-2359.

18. Fernandez ML. Distinct mechanism of plasma LDL lowering by dietary fiber in the Guinea pig : specific effects of pectin, guar gum, and psyllium. J.Lipid Res.1995,36:2394-2404

19. Lichtenstein HA. Dietary fat, carbohydrate, and protein: effects on plasma lipoprotein patterns. J. Lipis Res.2006.47:1661-1667.

20. Ganong WF. 2001. Review of medical physiology $11^{\text {th }}$ ed. New York. Mc Graw Hill P. 290-172 Silalahi, J. 2000. Fats, oils and fat subtitutes In Human nutrition. Indonesian Food and Nutrition Process. 7(2):56-66.

21. Gorinstein S, Leontowicz H, Krzeminski R, Gralak M, Delgado-Licon E, et al. Changes in plasma lipid and antioxidant activity in rats as a result of naringin and red grapefruit supplementation. J Agric Food Chem 2005;53:3223-8

22. Krummel DA. Medical Nutrition Therapy in Cardiovaskuler Disease. In: Mahan LK, Escottstump S. Krause's Food, Nutrition, and Diet Therapy $13^{\text {th }}$ Edition. Philadelphia: WB Saunders Company; 2008. 833-64.

23. Mayes PA. Sintesis, pengangkutan, dan ekskresi kolesterol. Dalam: Murray RK, Granner DK, Mayes PA, Rodwell VW, editor. Biokimia harper. Edisi 25. Jakarta: EGC; 2003

24. Myers J. Exercise and Cardiovascular health. Circulation. 2003;107:e2-e5. 